Original Research Article

\title{
Evaluation of the analgesic efficacy of garlic shoots extract in experimental pain models in mice
}

\author{
Suresh V. Dange ${ }^{1}$, Jill Mathew ${ }^{2}$, Angana Datta ${ }^{3}$, Abhijeet V. Tilak ${ }^{4}$, Makrand Jadhav ${ }^{5}$
}

${ }^{1}$ Professor, ${ }^{4}$ Head of

Department, ${ }^{5}$ Assistant

Professor, Dr. D. Y. Patil

Medical College, Pune,

Maharashtra, India

${ }^{2}$ Assistant Professor, Believers

Church Medical College,

Thiruvalla, Kerala, India

${ }^{3}$ Assistant Professor,

Department of Pharmacology,

Burdhawan Medical College,

Mangalore, Karnataka, India

Received: 07 November 2016

Accepted: 16 November 2016

*Correspondence to:

Dr. Jill Mathew,

Email: jillmathew25@

gmail.com

Copyright: (C) the author(s), publisher and licensee Medip Academy. This is an openaccess article distributed under the terms of the Creative Commons Attribution NonCommercial License, which permits unrestricted noncommercial use, distribution, and reproduction in any medium, provided the original work is properly cited.

\begin{abstract}
Background: Garlic shoot and leaves are discarded as a waste material. Garlic has many properties like anti-inflammatory, anti-arthritic, anti-oxidant, dyslipidemic, anti-cancer, anti-infective therefore in the present study Garlic shoot extract (GSE) preparation was evaluated for its analgesic efficacy by making use of different central and peripheral pain models. So this study was performed using experimental central and peripheral pain models in mice.

Methods: The analgesic efficacy of GSE was assessed by employing different pain models such as i)Hot plate and tail flick tests for central analgesia ii) $4 \%$ sodium chloride induced writhing as peripheral analgesic model. The percentage inhibition of writhes and prolongation of reaction time were the parameters of evaluation. The results obtained were analysed by ANOVA and Student's unpaired " $\mathrm{t}$ "- test.

Results: GSE treatment $(250 \mathrm{mg} / \mathrm{kg}$ and $500 \mathrm{mg} / \mathrm{kg})$ reduced writhing episodes significantly in $4 \% \mathrm{NaCl}$ induced writhing in mice as compared to control indicating its analgesic effect. The highest percentage inhibition of pain was seen with $500 \mathrm{mg} / \mathrm{kg}$ of GSE. GSE treatment, in Hot plate and Tail - flick methods significantly prolonged the reaction time at 90,120 minutes.

Conclusions: Garlic shoot extract (GSE) was found to be effective in all three models of experimental pain. However it is less potent than standard analgesic drugs and could be employed safely in higher doses.
\end{abstract}

Keywords: Analgesic efficacy, Garlic Shoot Extract, Pain Models

\section{INTRODUCTION}

Pain is the most common symptom for seeking the physician $^{1}$ advice. As long-term use of conventional analgesics is associated with significant toxicity. Hence there is a need for new analgesics. Garlic is a global natural herb with medicinal properties ${ }^{2}$ like hypoglycemic ${ }^{3}$, memory enhancing ${ }^{4}$, anti-oxidant ${ }^{5}$, antidepressant $^{6}$, anaesthetic ${ }^{7}$, wound healing ${ }^{8}$ and antiinflammatory ${ }^{9}$ in various animal models. In addition onion extract have been suggested to possess analgesic effects. Hence garlic shoot extract was chosen for present study.

\section{METHODS}

Albino mice of either sex $(20-25 \mathrm{~g})$ were used for this study. Mice were housed in standard polypropylene cages .The experimental protocol was approved by the "Institutional Animal Ethics Committee" [IAEC]. Aspirin (India chemical Co., New Delhi) Pentazocine (Fortwin, Ranbaxy) were used for this study. The garlic plants were authenticated from Botanical survey of India, Pune Maharashtra. The cleaned shoot was washed with distilled water. To extract the juice, $1.5 \mathrm{~kg}$ of the material crushed manually using a mortar and pestle, centrifuged and filtered. The supernatant obtained was concentrated using vacuum evaporator stored in a deep freezer. Stock 
solution of $10 \mathrm{mg} / \mathrm{ml}$ was obtained. A pilot study was conducted with garlic shoot extract $(75 \mathrm{mg} / \mathrm{kg}, 125 \mathrm{mg} / \mathrm{kg}$, $250 \mathrm{mg} / \mathrm{kg}, 500 \mathrm{mg} / \mathrm{kg}$ ) to assess the appropriate dose of the study. The analgesic efficacy was observed at few doses and the same was used for the final study.

\section{Experimental evaluation of analgesic efficacy}

Prior to employing the different methods to study the analgesic efficacy (physical, thermal and chemical models of pain) a preliminary screening was done. Those animals showing reaction time of less than 8 seconds were included in the study and the rest were excluded.

Group I: Control group treated with distilled water

Group II: Test group treated with GSE $125 \mathrm{mg} / \mathrm{kg}$ body weight p.o.

Group III: Test group treated with GSE $250 \mathrm{mg} / \mathrm{kg}$ body weight p.o.

Group IV: Test group treated with GSE $500 \mathrm{mg} / \mathrm{kg}$ body weight p.o.

Group V: Aspirin 50mg/kg body weight orally for peripheral pain models.

Pentazocine $10 \mathrm{mg} / \mathrm{kg}$ body weight i.p. for both central pain models $4 \% \mathrm{NaCl}$ induced Writhing Method $^{12}$

Analgesic activity of GSE was assessed by counting the number of writhes induced by $1 \mathrm{ml} / \mathrm{kg}$ of $4 \% \mathrm{Na} \mathrm{Cl}$. Animals that do not exhibit writhing within 30 seconds were discarded. GSE in $125 \mathrm{mg} / \mathrm{kg}, 250 \mathrm{mg} / \mathrm{kg}, 500 \mathrm{mg} / \mathrm{kg}$ doses and Aspirin 50mg/kg was administered p.o. to the different treatment groups 60 min before the $4 \% \mathrm{NaCl}$ administration. The number of writhes was observed for about 10 minutes and the animals showing no response were defined analgesic positive. Percentage inhibition of the number of writhes was taken as index of analgesia. \% inhibition $=\mathrm{Nc}-\mathrm{Nt} / \mathrm{Nc} \times 100 . \mathrm{Nc}=$ mean no: of writhes in the control group. $\mathrm{Nt}=$ mean no: of writhes in the test group. No response $=$ analgesic positive Writhing response $=$ analgesic negative .
Hotplate method: Mice were placed on a hot-plate at $55^{\circ} \pm 5^{\circ} \mathrm{C} .13$ The latency to lick the paw was the reaction time. A cut off time of 30 seconds was followed to avoid any thermal injury to the paws. GSE was given in the doses of $125 \mathrm{mg} / \mathrm{kg}, 250 \mathrm{mg} / \mathrm{kg}, 500 \mathrm{mg} / \mathrm{kg}$ per orally at 0 min. The reaction time of the mice was recorded at 30 , $60,90,120 \mathrm{~min}$ after drug administration. The mean of the observed values was considered for statistical analysis.

Tail Flick method: The analgesic activity was determined by measuring drug-induced changes in the sensitivity of the mice to heat stress applied to their tails. A Tail flickAnalgesiometer was employed for this experiment. Intensity of the current passing through the naked nicrome wire was 6 ampere. The distance between the heat source and the tail skin was $1.5 \mathrm{~cm}$ and cut-off reaction time was fixed at 10 second to avoid tissue. The garlic shoot extract was given in the doses of $125 \mathrm{mg} / \mathrm{kg}$, $250 \mathrm{mg} / \mathrm{kg}, 500 \mathrm{mg} / \mathrm{kg}$ per orally at $0 \mathrm{~min}$.The reaction time was observed at $30.60,90,120 \mathrm{~min}$ after drug administration. The mean of the observed values was considered for statistical analysis. All data were expressed as mean \pm SEM. Statistical analysis was carried out by ANOVA and Student's unpaired ' $t$ "'- test for peripheral as well as central models. Multiple comparisons were done with Bonferroni's adjusted t-test. The values considered significant at $\mathrm{P}<0.05$ as compared to control Figures are mean \pm SD.

\section{RESULTS}

Table 1: Effect of GSE on $4 \% \mathrm{NaCl}$ induced writhing in mice.

\begin{tabular}{|llc|}
\hline $\begin{array}{l}\text { Treatment } \\
\text { (mg/kg,p.o) }\end{array}$ & $\begin{array}{l}\text { Number of } \\
\text { writhes }\end{array}$ & $\%$ inhibition \\
\hline Control & $25.9 \pm 4.4$ & $0 \%$ \\
\hline $\begin{array}{l}\text { Aspirin } 20 \\
\mathrm{mg} / \mathrm{kg}\end{array}$ & $5 \pm 0.62$ & $77 \%$ \\
\hline GSE $125 \mathrm{mg} / \mathrm{kg}$ & $16.92 \pm 1.04$ & $22 \%$ \\
\hline GSE $250 \mathrm{mg} / \mathrm{kg}$ & $12.67 \pm 2.59$ & $41 \%$ \\
\hline GSE $500 \mathrm{mg} / \mathrm{kg}$ & $8.5 \pm 1.71$ & $61 \%$ \\
\hline P $<0.05$ as compared to control Figures are mean \pm SD. \\
\hline
\end{tabular}

Table 2: Effect of GSE on latency of paw licking in hot plate method.

\begin{tabular}{|llllll|}
\hline \multicolumn{6}{|l}{ Latency of paw licking in seconds } \\
\begin{tabular}{|l} 
Treatment \\
(mg/kg p.o)
\end{tabular} & $0 \mathrm{~min}$ & $30 \mathrm{~min}$ & $60 \mathrm{~min}$ & $90 \mathrm{~min}$ & $120 \mathrm{~min}$ \\
\hline Control & $5.01 \pm 1.10$ & $5.13 \pm 1.09$ & $5.74 \pm 1.07$ & $5.14 \pm 1.07$ & $4.70 \pm 1.13$ \\
\hline $\begin{array}{l}\text { Pentazocine } \\
(10 \mathrm{mg} / \mathrm{kg} \text { i.p. })\end{array}$ & $6.74 \pm 1.78$ & $12.24 \pm 4.14^{*}$ & $10.09 \pm 2.05 *$ & $8.56 \pm 2.15$ & $7.32 \pm 1.74$ \\
\hline GSE $125 \mathrm{mg} / \mathrm{kg}$ & $4.71 \pm 1.12$ & $8.48 \pm 1.90$ & $8.34 \pm 1.99$ & $8.58 \pm 1.35$ & $10.00 \pm 2.31^{*}$ \\
\hline GSE $250 \mathrm{mg} / \mathrm{kg}$ & $6.64 \pm 1.24$ & $8.58 \pm 1.33$ & $8.26 \pm 1.03$ & $10.53 \pm 1.06^{*}$ & $11.01 \pm 1.53 *$ \\
\hline GSE $500 \mathrm{mg} / \mathrm{kg}$ & $6.30 \pm 1.25$ & $7.89 \pm 1.23$ & $11.01 \pm 1 . .23^{*}$ & $12.29 \pm 1.31^{*}$ & $12.23 \pm 4.31^{*}$ \\
\hline
\end{tabular}

${ }^{*} \mathrm{p}<0.05$, when compared with control group. Fig. are Mean \pm SD. 
Table 3: Effect of GSE of tail flicking with radiant heat method.

Latency of tail flicking in seconds

\begin{tabular}{|c|c|c|c|c|c|}
\hline $\begin{array}{l}\text { Treatment } \\
\text { (mg/kg p.o) }\end{array}$ & $0 \min$ & $\begin{array}{l}\text { Treatment } \\
\text { (mg/kg p.o) }\end{array}$ & $0 \min$ & $\begin{array}{l}\text { Treatment } \\
\text { (mg/kg p.o) }\end{array}$ & $0 \min$ \\
\hline Control & $4.38 \pm 2.26$ & Control & $4.38 \pm 2.26$ & Control & $4.38 \pm 2.26$ \\
\hline $\begin{array}{l}\text { Pentazocine } \\
\text { (10mg/kg i.p) }\end{array}$ & $4.63 \pm 2.72$ & $\begin{array}{l}\text { Pentazocine } \\
\text { (10mg/kg i.p) }\end{array}$ & $4.63 \pm 2.72$ & $\begin{array}{l}\text { Pentazocine } \\
\text { (10mg/kg i.p) }\end{array}$ & $4.63 \pm 2.72$ \\
\hline GSE $125 \mathrm{mg} / \mathrm{kg}$ & $3.35 \pm 2.13$ & GSE $125 \mathrm{mg} / \mathrm{kg}$ & $3.35 \pm 2.13$ & GSE $125 \mathrm{mg} / \mathrm{kg}$ & $3.35 \pm 2.13$ \\
\hline GSE $250 \mathrm{mg} / \mathrm{kg}$ & $3.37 \pm 1.00$ & GSE $250 \mathrm{mg} / \mathrm{kg}$ & $3.37 \pm 1.00$ & GSE $250 \mathrm{mg} / \mathrm{kg}$ & $3.37 \pm 1.00$ \\
\hline GSE $500 \mathrm{mg} / \mathrm{kg}$ & $3.98 \pm 1.87$ & GSE $500 \mathrm{mg} / \mathrm{kg}$ & $3.98 \pm 1.87$ & GSE $500 \mathrm{mg} / \mathrm{kg}$ & $3.98 \pm 1.87$ \\
\hline
\end{tabular}

*p $<0.05$, when compared with control group. Fig. are Mean \pm SD.

The Garlic shoot extract (GSE) at doses of $125 \mathrm{mg} / \mathrm{kg}$, $250 \mathrm{mg} / \mathrm{kg}$ and $500 \mathrm{mg} / \mathrm{kg}$ p.o. and Aspirin $20 \mathrm{mg} / \mathrm{kg}$ po which was used as standard exhibited a significant reduction $(\mathrm{P}<0.05)$ in the number of writhes as compared to control [Table 1]. The percentage inhibition of the number of writhes were $41 \%$ with GSE $250 \mathrm{mg} / \mathrm{kg}$ and $61 \%$ with GSE $500 \mathrm{mg} / \mathrm{kg}$ which was comparable to aspirin.

In the hotplate method, GSE in the doses of 250and $500 \mathrm{mg} / \mathrm{kg}$, significantly prolonged the reaction time in mice at 90and 120 minutes as compared to control $(p<0.05)$ [Table 2] whereas GSE in the dose of $125 \mathrm{mg} / \mathrm{kg}$ significantly prolonged the reaction time as compared to control only at $120 \mathrm{~min}(\mathrm{p}<0.001)$.GSE at the dose of $500 \mathrm{mg} / \mathrm{kg}$ showed a latency time at $60,90,120 \mathrm{~min}$ which was comparable to pentazocine $(p<0.05)$.Pentazocine showed significant findings from 30 minutes onwards $(p<0.01)$ when compared to control. In tail flick method GSE $250 \mathrm{mg} / \mathrm{kg}$ as well as GSE $500 \mathrm{mg} / \mathrm{kg}$ showed significant latency as compared to control.GSE $500 \mathrm{mg} / \mathrm{kg}$ at $60 \mathrm{~min}$ was comparable to pentazocine at $30 \mathrm{~min}$.

\section{DISCUSSION}

Analgesics are medications used to relieve pain of multiple etiologies without reducing the consciousness of the patient. This is generally achieved by interfering with the way the pain message is transmitted by the nerves. The present study was carried out using different experimental pain mode to evaluate the peripheral and central analgesic activity of GSE.

The garlic shoot extract showed analgesic activity in both central and peripheral models of pain as compared to control and at higher doses comparable to standard. Writhing induced by $4 \% \mathrm{Na} \mathrm{Cl}$ solution is a sensitive and specific test for predicting the peripheral analgesic activity of a compound in man. ${ }^{12}$ Bhavyapraakash Nighantu describes Garlic to be used as 'kookshi shoolahanta' (alleviating pain in abdomen). ${ }^{14}$ Intraperitonealinjection of $4 \% \mathrm{NaCl}$, the nociceptive response is due to release of endogenous substances such as bradykinin and prostaglandins and other mediators into the peritoneum, which stimulate the nociceptive endings sensitive to analgesic, anti-inflammatory drugs. In this study we found that administration of GSE in the doses of
125,250 and $500 \mathrm{mg} / \mathrm{kg}$ orally $60 \mathrm{~min}$ before administration of $\mathrm{NaCl}$ resulted in significant decrease in the number of writhes. The percentage inhibition of writhes was found to be $22 \%, 41 \%$ and $61 \%$ with the respective doses. Aspirin in the dose of $20 \mathrm{mg} / \mathrm{kg}$ resulted in $77 \%$ inhibition in the number of writhes.

A study by Jayanthi et al using Garlic powder in the doses of 75,150 and $300 \mathrm{mg} / \mathrm{kg}$ orally $60 \mathrm{~min}$ before administration of aceticacid resulted in significant decrease in the number of writhes as compared to control. The percentage inhibition of writhes was 33\%, 57\% and $72 \%$ with the respective doses. Indomethacin in the dose of $10 \mathrm{mg} / \mathrm{kg}$ resulted in $91 \%$ inhibition in the number of writhes. ${ }^{15}$ Farjana et al studied the anti-nociceptive activity of methanolic extract of Allium sativum cloves (MEAS) in acetic acid induced writhing in mice. The extract was given in the doses of 50, 100, 200 and 400 $\mathrm{mg} / \mathrm{kg}$ and resulted in significant reductions in the number of writhings by $27.6 \%, 41.4 \%, 51.7 \%$ and $55.2 \% .{ }^{16}$ In our study, GSE given in the dose of 250 and $500 \mathrm{mg} / \mathrm{kg}$ resulted in $41 \%$ and $61 \%$ inhibition of writhing. This shows that the shoot extracts also possess analgesic activity.

The hot-plate method as well as tail-flick method is most commonly used tests, considered to be selective for the centrally acting analgesic drugs. In both these models of experimental pain, GSE administered in the doses of 250 and $500 \mathrm{mg} / \mathrm{kg}$ per orally, significantly prolonged the reaction time in mice at $60,90 \mathrm{~min}$ as compared to control. GSE at $500 \mathrm{mg} / \mathrm{kg}$ showed comparable results to the standard at 90 and $120 \mathrm{~min}$. Like wise in the radiant heat method the tail flick response with GSE 250 and $500 \mathrm{mg} / \mathrm{Kg}$ was significantly increased as compared to control and GSE $500 \mathrm{mg} / \mathrm{kg}$ was comparable to standard at $60 \mathrm{~min}$. Acute toxicity LD50 studiesof aqueous garlic extract, garlic powder, and alcoholic garlicextract showed no mortality in mice till doses of $5 \mathrm{~g} / \mathrm{kg}$ bodyweight. Plant extracts with LD50 less than $10 \mathrm{mg} / \mathrm{kg}$ body weightare considered highly toxic and those with LD50 greater than $50 \mathrm{mg} / \mathrm{kg}$ body weight are considered non-toxic. ${ }^{17}$ Thus garlic can be considered as nontoxic and higher doses may be employed.

Garlic leaves and shoots contains following phytoconstituents like flavanoids, alkaloids and sulfur 
compounds. The major phytoconstituents are Thioacremonone, Allicin, DADS, DATS, Ajoene and Quercetin. ${ }^{5}$ Some of this may inhibit cyclooxygenase ${ }^{16}$ peripherally and act on opioid receptors centrally leading to analgesia. The mechanism of analgesic activity of Garlic shoots extract could be probably due to the blockade of inflammatory pain mediators because of its established anti-inflammatory properties in carrageenan inducedrat paw edema and cotton pellet induced dry granulomaweight. Moreover the release of PGE2 a byproduct of Arachidonic acid metabolism is directly dependent on generation of freeradicals/reactive oxygen species. Allyl cysteine, alliin, allicin, andallyl disulfide are protective sulphur compounds against free radical damage. ${ }^{18}$

Analgesia can result from decline in plasticity at dorsal root via deprivation of substance $\mathrm{P}$ or glycine or glutamate from the nerve endings. Garlic is reported to decrease Glutamate levels and therefore may result in analgesia in dorsal horn neurons. Ajoene found in garlic has been proposed to inhibit the pain receptors at dorsal root of spinal cord thus resulting in inhibition of pain signal transduction. ${ }^{10}$ Various parts of Garlic plant are rich in the phytoconstituents allicin and ajoene making clear that even the other parts of the garlic plant can be utilized in higher doses to potentiate the standard analgesics.

We have not studied the combination of standard drugs with the garlic-shoot extract It might be possible that garlic shoot extract potentiates analgesic activity of standard drugs which may result in lower dosages of standard drugs minimizing the adverse effects of such drugs.

\section{ACKNOWLEDGEMENT}

We want to acknowledge the help of pharmacy college and biochemistry departments of Dr. D.Y. Patil Pune for their timely help.

Funding: No funding sources Conflict of interest: None declared

Ethical approval: The study was approved by the Institutional Ethics Committee

\section{REFERENCES}

1. Gureje O, Korff MV, Simon GE, Gater R. Persistent Pain and Well-being: A World Health Organization Study in Primary Care. JAMA. 1998;280:147-51.

2. Balch PA. Prescription for Herbal healing: An easy-touse A-Z reference to hundreds of common disorders and their herbal remedies. New York: Avery Publishing groups, 2012.p: 69
3. Shakya VK, Saxena RC, Shakya A. Effect of ethanolic extract of Allium sativum bulbs on streptozotocin induced diabetic rats. J Chem Pharm Res. 2010;2:171-5.

4. Cervantes MI. Comparison of antioxidant activity of hydroethanolic fresh and aged garlic extracts and their effects on cerebral ischemia. Food Chemistry. 2013;140:343-52.

5. Singla V, Bajaj JD, Bhaskar R, Kumar B. Garlic :A concise drug review with probable clinical uses. International journal of Drug Development and research.2012;4:9-17

6. Hashemi HJ. The effects of hydro alcoholic -extracts of garlic on depression induced by reserpine in rats.Indian J of Neurology. 2009; 7:527-34.

7. Hashemi HJ, Jaferi H, Kazemi S. Effect of using garlic before anaesthesia on the process of anesthesia with Halothane and Thiopental in male mice. $\mathrm{J}$ of Birjand University of medical sciences. 2008;14:15-20.

8. Alfars AA. The effect of garlic aqueous extract on infected wound healing in goat. The scientific journal of Vet.Med. 2007;6:14-5.

9. Jayanthi MK. Anti-inflammatory effects of Allium sativum in experimemtal rats. Biomed Journal. 2011;1(31):88.

10. Nasri S, Anoush M, Khatami N. Evaluation of analgesic and anti-inflammatory effects of fresh onion juice in experimental animals. African Journal of Pharmacy and Pharmacology. 2012;6:1679-84.

11. Abdulla FH. Allium sativum L. extract prevents methyl mercury-induced cytotoxicity in peripheral blood vessels.Food and Chem tox. 2010;48:417-21.

12. Ghosh MN, Fundamentals of Experimental Pharmacology. 5th Ed. Kolkata (India): Hilton and Company; 2011; Chapter 24, Evaluation of analgesic agents. p. 152

13. Schleyerbach R. Analgesic, anti-inflammatory and antipyretic activity. In Vogel HG editor. Drug discovery and evaluation.2nd ed. Germany: Springer; 2002. p.696.

14. Pandit V, Dwivedi V. Haritakyadivarga. In Bhavprakash Nighantu. $9^{\text {th }}$ ed.New-Delhi: Motilal Banarasidas Publications 1998; shloka no: 204-210:79.

15. Jayanthi MK. Exper imental animal studies on analgesic and anti-nociceptive activity of Allium sativum(Garlic) powder. IJRRMS. 2012;2:1-5.

16. Farjana. Antinociceptive activity Studies with Methanol Extract of Onion, Garlic and Ginger in Mice. Advances in Natural and Applied Sciences Academic Journal 2014; 8 (8):169 17. Chung LY.The antioxidant properties of garlic compounds: allyl cysteine,allin ,allylcysteine and allyl disulfide. J Med Food. 2006;9(2):205-13.

17. Karber C. Beitrag zur kollektiven behandlung pharmakologischer reihenversuche. NaunynSchmiedebergs Archiv fuer experimentelle Pathologie und Pharmakologie.1936;162:480-2.

18. Chung LY. The antioxidant properties of garlic compounds: allyl cysteine, allin, allylcysteine and allyl disulfide. J Med Food. 2006;9(2):205-13.

Cite this article as: Dange SV, Mathew J, Datta A, Tilak AV, Jadhav M. Evaluation of the analgesic efficacy of garlic shoots extract in experimental pain models in mice. Int J Basic Clin Pharmacol 2016;5:2393-6. 